\title{
Systematic review: antihypertensive drug therapy in patients of African and South Asian ethnicity
}

\author{
Lizzy M. Brewster ${ }^{1,2} \cdot$ Gert A. van Montfrans $^{1,2} \cdot$ Glenn P. Oehlers ${ }^{3} \cdot$ \\ Yackoob K. Seedat ${ }^{4}$
}

Received: 9 December 2015 / Accepted: 22 February 2016/Published online: 30 March 2016

(C) The Author(s) 2016. This article is published with open access at Springerlink.com

\begin{abstract}
Despite the large differences in the epidemiology of hypertension across Europe, treatment strategies are similar for national populations of white European descent. However, hypertensive patients of African or South Asian ethnicity may require ethnic-specific approaches, as these population subgroups tend to have higher blood pressure at an earlier age that is more difficult to control, a higher occurrence of diabetes, and more target organ damage with earlier cardiovascular mortality. Therefore, we systematically reviewed the evidence on antihypertensive drug treatment in South Asian and African ethnicity patients. We used the Cochrane systematic review methodology to retrieve trials in electronic databases including CENTRAL, PubMed, and Embase from their inception through November 2015; and with handsearch. We retrieved 4596 reports that yielded 35 trials with 7 classes of antihypertensive drugs in 25,540 African ethnicity patients. Aside from the well-known blood pressure efficacy of calcium channel blockers and diuretics, with lesser effect of ACE inhibitors and beta-blockers, nebivolol was not more effective than placebo in reducing systolic blood pressure
\end{abstract}

Lizzy M. Brewster

1.m.brewster@amc.uva.nl

1 Department of Vascular Medicine, F4-222, Academic Medical Center, University of Amsterdam, Meibergdreef 9, 1105 AZ Amsterdam, The Netherlands

2 Department of Internal Medicine, Academic Medical Center, University of Amsterdam, Amsterdam, The Netherlands

3 Department of Cardiology, Academic Hospital of Paramaribo, Paramaribo, Suriname

4 Nelson R Mandela School of Medicine, Faculty of Health Sciences, University of KwaZulu Natal, Private Bag. 7, Congella, 4013 Durban, South Africa levels. Trials with morbidity and mortality outcomes indicated that lisinopril and losartan-based therapy were associated with a greater incidence of stroke and sudden death. Furthermore, 1581 reports yielded 16 randomized controlled trials with blood pressure outcomes in 1719 South Asian hypertensive patients. In contrast with the studies in African ethnicity patients, there were no significant differences in blood pressure lowering efficacy between drugs, and no trials available with mortality outcomes. In conclusion, in patients of African ethnicity, treatment initiated with ACE inhibitor or angiotensin II receptor blocker monotherapy was associated with adverse cardiovascular outcomes. We found no evidence of different efficacy of antihypertensive drugs in South Asians, but there is a need for trials with morbidity and mortality outcomes. Screening for cardiovascular risk at a younger age, treating hypertension at lower thresholds, and new delivery models to find, treat and follow hypertensives in the community may help reduce the excess cardiovascular mortality in these high-risk groups.

Keywords Hypertension - Antihypertensive drugs . Systematic review - African continental ancestry group . South Asian · Ethnic groups

\section{Background}

The increasing ethnic diversity of the European population is likely to bring a greater diversity in disease and disease patterns to the doctor's office. Around 33 million immigrants live in the European Union. It is estimated that a third of these immigrants are from other European countries, while immigrants from non-European countries are mainly African ( $25 \%$, with more than half North-African), or Asian (21\%) [1]. 
Despite the large differences in the epidemiology of hypertension across Europe [2], treatment strategies tend to be similar for national populations of white European descent. Nevertheless, in particular patients of South Asian and sub-Saharan African descent tend to have more hypertension and diabetes, and more target organ damage and cardiovascular mortality at a younger age than patients of white European descent. In addition, hypertension occurs earlier in life in these patients groups, bringing about a faster progression from normotension to hypertension, with higher mean blood pressures than in white patients [3-22].

While little is reported regarding the pathophysiology of hypertension in South Asian patients, abundant data in patients of African descent indicate there is greater salt sensitivity, blunted nocturnal dipping, and enhanced vasoconstriction in this group [3-8, 10, 12-14, 16-21]. South Asians are genetically diverse, but members of this population subgroup share a high cardiovascular risk, with more severe atherosclerosis reported, and ischaemic end organ damage at a younger age even with lower cholesterol levels than in whites [11]. Thus, hypertension seems to be a more aggressive disease, occurring at a younger age in these patient groups. This could have important implications for hypertension screening and management.

In patients of all ethnicity groups, non-pharmacological intervention to reduce hypertension and cardiovascular risk, including dietary adjustments, physical exercise, weight reduction, smoking cessation, and reduction of excessive alcohol intake should be part of hypertension management. In addition, stress reduction and relaxation exercise might aid in reducing blood pressure [23]. In particular, diets high in potassium and calcium and low in sodium, such as the (DASH) diet, have documented blood pressure lowering efficacy [24-30]. These measures are thought to be effective in hypertensives across ethnic groups, but increasing evidence indicates that the very low salt intake $(<1500 \mathrm{mg}$ or $<65 \mathrm{mmol}$ sodium per day) recommended for persons of African ethnicity [31-33], has been associated with increased mortality in this group, potentially related to activation of the renin angiotensin system $[31,32]$. Even so, high salt intake $(>2300 \mathrm{mg}$ or $>100$ mmol sodium per day) is still considered detrimental to cardiovascular health [32], and moderate salt restriction continues to have a place in the management of hypertension in all ethnic groups.

However, most patients with hypertension will need drug therapy aside life style measures. Therefore, in this paper, we review the evidence on randomized trials of antihypertensive drug treatment in African and South Asian ethnicity patients, and propose practical approaches for the European situation.

\section{Methods}

The participation of patients of ethnic minority groups in major, international clinical trials is generally too low to calculate the primary outcome with sufficient power [34]. Therefore, we systematically reviewed the evidence on the efficacy of antihypertensive drug therapy to reduce blood pressure and morbidity and mortality outcomes, and pooled the existing data.

Systematic searches were conducted in November 2015, with our previous systematic review on patients of African ethnicity $[16,17]$ updated and expanded. In brief, we used the Cochrane systematic review methodology, [35] and defined a highly sensitive search strategy to retrieve original reports of randomized controlled trials in hypertensive African and South Asian ethnicity patients, providing original quantitative data on the effect of antihypertensive monotherapy on blood pressure (trial duration at least 2 weeks) vs concurrent placebo treatment, or antihypertensive mono or combination therapy on morbidity or mortality outcomes (trial duration at least 1 year).

We included only trials with major drug classes in adults, men and non-pregnant women, with uncomplicated primary hypertension (no history of, or current cardiovascular events or ESRD). Trials that considered oral antihypertensive treatment with thiazide and thiazide-like diuretics, calcium-channel blockers, centrally acting agents, peripheral adrenergic neuron antagonists, angiotensin-converting enzyme (ACE) inhibitors, or angiotensin II receptor blockers were eligible for inclusion.

We conducted separate searches and data analysis for these two ethnic groups. Searches were performed in electronic databases (Embase, PubMed, Cochrane Library CENTRAL, Literatura Latino-Americana y del Caribe en Ciencias de la Salud (LILACS), African Index Medicus, and for South Asian patients, IndMED) from their inception through November 2015, without language restriction.

These databases have different software and therefore different search languages, but a typical search strategy for trials in patients of African ethnicity was, "(Black* OR Afri* OR AFRO* OR Creole OR Carribean OR Caribbean OR negr* OR ethnic* OR blacks) AND (hypertension OR antihypertensive) AND randomized"; and for South Asians: the first step was "(South Asian OR South Asians OR India OR Indian OR Hindustani OR Bangladesh OR Nepal OR Sri Lanka OR Ceylon OR Pakistan)".

Search yields from all databases were considered and analysed separately to prevent merging errors and to enhance trial retrieval. Furthermore, we contacted experts and performed hand search. We did not include trials in diabetics only, with experimental drugs, or with complementary medicines. 
We used data extraction forms to collect trial data. With pilot searches, we retrieved very few placebo controlled trials in South Asians, and decided to review drug vs drug trials in this group. For drug vs drug trials with multiple treatment arms, we followed the Cochrane handbook methodology and combined the comparison groups into one group of "other drugs" [35]. African or South Asian descent (ancestry, or ethnicity) were defined as respectively of sub-Saharan African descent, or Indian subcontinental descent as indicated by the authors. We included only randomized controlled trials, and methodological quality was further assessed using the Jadad score, based on the description of randomization, blinding, and accountability of all patients, including withdrawals in each of the study groups, and the underlying reasons. Subgroups were based on gender and geographical location, and compliance data were assessed in trials with mortality outcomes.

\section{Statistical analysis}

Quantitative analysis of outcomes was based on intention-totreat results (primary) and per protocol analysis (secondary). We included data from the first part of crossover studies when such data were available; if not, we included the data these studies provided. Our measure of effect for each study was difference in means (in $\mathrm{mmHg}$ ) for systemic arterial blood pressure (continuous measure) and relative risk (RR) for dichotomous data. In addition, we calculated achievement of target diastolic blood pressure (DBP $<90 \mathrm{mmHg}$, or reduction of $\geq 10 \mathrm{mmHg}$, or $\geq 10 \%$, as defined by the author) as the weighted mean of placebo-corrected results per drug class, or in South Asians, vs other drug types.

Missing standard deviations were imputed per drug class. We clinically assessed studies for heterogeneity in patient characteristics, interventions, and outcomes, to decide whether studies should be pooled. Furthermore, we used $I^{2}$ statistics to quantify the proportion of total variation in the estimates of treatment effect that was due to heterogeneity. We planned to not aggregate results with a high variation across studies $\left(I^{2} \geq 75 \%\right)[17,35]$. When we aggregated studies, we conservatively used the random effects model to estimate the average intervention effect. Data in square brackets are $95 \%$ confidence intervals, unless indicated otherwise. We used Review Manager (RevMan) software, version 5 (Cochrane Collaboration, Oxford, UK) for the analyses.

\section{Results}

\section{Patients of African ethnicity}

Full reports or abstracts from 4596 references of papers yielded 35 trials with 7 classes of antihypertensive drugs, in
25,540 patients. Blood pressure was the main outcome measure in 28 of these trials (Figs. 1, 2; Table 1) [36-66], and morbidity or mortality in seven trials (Table 2) [6788]. Our 2015 update included two new trials with blood pressure outcomes on nebivolol [46, 53], and eight new reports on morbidity and mortality outcomes (five reports with new subgroup analyses from the ALLHAT and LIFE, and AASK trials, and three new reports of the VALUE, INVEST, and ACCOMPLISH trials) [81-88]. Trials were clinically comparable in describing the results of randomized controlled interventions with antihypertensive drugs in African ethnicity patients with hypertension, but the age range, inclusion blood pressure, drugs and drug dose varied (Tables 1, 2). Since we retrieved only two new blood pressure trials considering monotherapy with nebivolol vs placebo, the results of the 2015 update are similar to the data reported previously, as depicted in Fig. 2a, b. As a post hoc outcome, nebivolol was analysed separately as well because of the presumed different mechanism of action [46, 53]. Nebivolol is thought to enhance nitric oxide generation [46, 53]. However, the pooled weighted mean difference in systolic (SBP) and diastolic pressure vs placebo of these two trials is respectively SBP $-3.38 \mathrm{mmHg}, 95 \% \mathrm{CI}[-8.38 ; 1.62] ; I^{2} 33 \%$; and DBP $-5.00 \mathrm{mmHg}, 95 \%$ CI $[-7.41 ;-2.59]\left(I^{2}=0 \%\right)$. With the addition of these relatively large trials to the pooled analysis (Fig. 2a) the size of the effect of beta-adrenergic blockers on systolic blood pressure was similar, but the confidence interval became narrower, and statistically significant from placebo [pooled estimate for systolic blood pressure without nebivolol $-3.53 \quad\left[\begin{array}{lll}-7.51 ; & 0.45]\end{array}\right.$ $\left(I^{2}=50 \%\right)$ [17], and with nebivolol -3.73 [-6.80; -0.66] $\left(I^{2}=44 \%\right)$, Fig. 2a].

Achievement of target DBP differed by drug class, calcium-channel blockers $46 \%$ (RR 3.39 [2.35; 4.90]; diuretics $31 \%$ (RR 2.49 [1.68; 3.69]; beta-adrenergic blockers $24 \%$ (RR 1.97 [1.43; 2.72]; centrally acting agents $23 \%$ (RR 2.22 [1.35; 3.63]; angiotensin II receptor blockers $19 \%(1.77$ [1.41; 2.21]; alpha-blockers $13 \%$ (RR 1.71 [1.02; 2.86]; and ACE inhibitors $10 \%$ (RR 1.35 (0.81; 2.26); with a RR of $>1.0$ indicating a beneficial effect.

Thus, the aggregated data show a greater effect of calcium blockers and diuretics, while beta-adrenergic blockers and ACE inhibitors are the least effective drugs to lower SBP and DBP, respectively. The cause of these differences in drug responses is largely unknown. Our findings are in accord with the suppressed activity of the renin-angiotensin-aldosterone system in hypertensive patients of African ethnicity, and the high activity of creatine kinase, promoting vasoconstriction and salt retention [8, 16]. As a consequence, patients of African ethnicity are significantly less sensitive to drugs that block the renin-angiotensinsystem (angiotensin-converting enzyme inhibitors and 
Fig. 1 Trial flow: patients of African ethnicity. Asterisk with results for African ethnicity patients in the Materson [47, 48], TAIM [57, 58], TOMHS $[59,60]$, SHEP ([68] and unpublished report), AASK [75, 76, 81] and ALLHAT [79, 80, 86, 88]; LIFE [73, 85, 87] studies contained in more than one report. Most excluded papers were not an RCT; and of the RCT's retrieved, most were either not an RCT in hypertensives, or an RCT's in other ethnic groups, an RCTs with combination therapy, drug vs drug trials, or in particular for morbidity and mortality trials, multiple overlapping reports concerning these trials

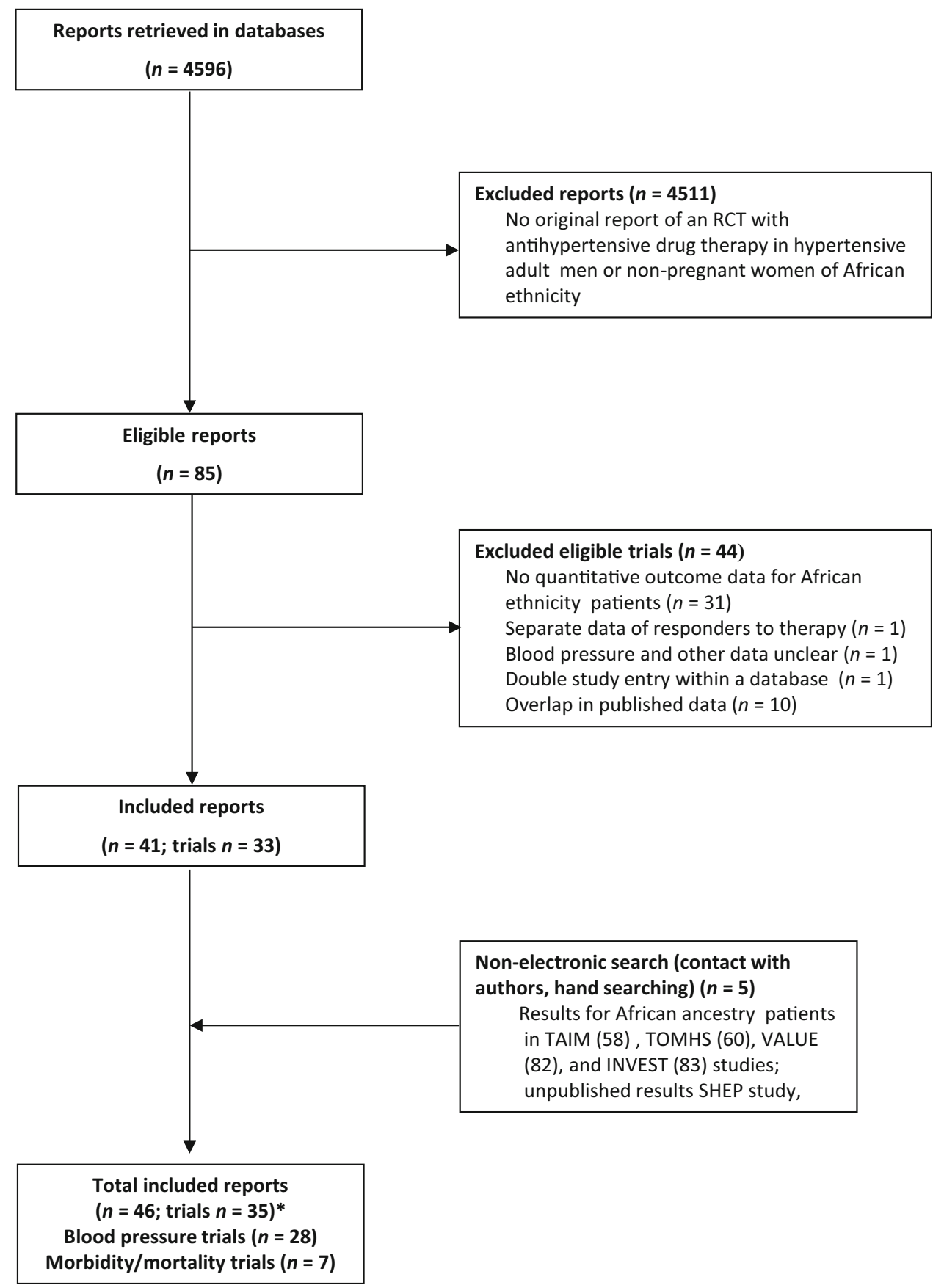

angiotensin II receptor blockers) and beta-blockers [16]. Genetic and pharmacokinetic differences do not fully explain these differences [16], but altered cellular functions based on high creatine kinase activity and enhanced phosphoryl group buffer function have been implied in this group, leading to enhanced ATP-dependent responses including greater contractility, salt retention and therapy failure $[16,18]$, as well as lower NO bioavailability $[8,16]$.

We predefined subgroups based on gender and on geographical location. However, only 3 small trials out of 28 trials with blood pressure outcomes reported data for men and women ( $N=146$ patients), and this was not further analysed [40, 45, 66]. When we separately analysed US/ Caribbean studies, calcium-channel blockers changed SBP by $-11.89 \mathrm{mmHg}$ (CI -14.12 to $-9.67 \mathrm{mmHg}$ ) and betablockers led to a change of $-4.83 \mathrm{mmHg}$ (CI -7.91 to $-1.75 \mathrm{mmHg}$ ); the size of the effect of alpha-blockers on DBP became heterogeneous. When we separately analysed data from African studies, however, only calcium-channel blockers remained more effective than placebo for all outcomes analysed. Diuretics did not significantly differ from placebo in achieving the DBP goal (relative risk 3.55 
[CI 0.41-31.05]), and ACE inhibitors, beta-blockers, and alpha-blockers did not significantly differ from placebo in reduction of SBP and DBP. None of the African studies used a cutoff baseline DBP of less than $114 \mathrm{mmHg}$, compared with 7 of the 15 US and Caribbean studies (Table 1). Thus, we could not determine whether the response of African patients truly differed from that of US and Caribbean patients or was rather related to higher baseline blood pressure levels.

We retrieved seven trials with morbidity and mortality outcomes (Table 2) [67-88]. Most included patients were older than 50 years with risk factors for cardiovascular disease, followed for 3-5 years, with cardiovascular events and mortality as main outcome measures. The Jadad scores ranged from 1 to 5 (Table 2). An average of three drugs was needed in an add-on strategy to reach blood pressure goals as defined in the trials. The majority of African descent participants (50-70\%) reached blood pressure control, but $95 \%$ needed combination therapy. In line with the blood pressure lowering efficacy of monotherapy, more patients on calcium blocker-based treatment reached goal blood pressure, while there was a reduced blood pressure lowering response in treatments based on initial monotherapy with angiotensin II receptor blockers or ACE inhibitors [82, 83, 86].

There was no statistical difference between the different treatment arms in primary morbidity and mortality outcomes (Table 2). The main side effects of long-term therapy were newly developed diabetes (diuretics $>$ calcium blockers $>$ ACE inhibitors), and a significantly greater occurrence of cough and angioedema with ACE inhibitors, 72 per $10,000(0.72 \%)$, vs diuretics $(0.04 \%)$, and calcium blockers $(0.06 \%)$ for African ethnicity patients in ALLHAT $[17,86]$.

In the SHEP study, the overall effect of diuretics on the primary outcome stroke in African ethnicity patients was not significantly different from placebo. In subgroup analysis, stroke risk reduced in women of African ethnicity (relative risk 0.36 [CI 0.16; 0.83]) but not in men (relative risk 0.98 [CI 0.39; 2.44]) [69]. However, treatment did reduce cardiovascular events as a secondary outcome (hazard ratio for all cardiovascular events, 0.50 (CI 0.32; 0.78) (unpublished results, SHEP trial investigators).

Furthermore, in the ACCOMPLISH trial, there was no significant difference in African ethnicity patients between the two treatment strategies in retarding the rate of progression of kidney disease, in contrast to patients of other ethnicities where amlodipine/benazepril-based therapy was more effective than hydrochlorothiazide/benazepril [84].

Although ACE inhibitor-based treatment yielded better clinical outcomes in kidney disease in the AASK trial [75], there was no difference in prevention of cardiovascular events by drug type [81], while the results of the ALLHAT trial indicates that cardiovascular morbidity outcomes were worse with treatments based on inhibitors of the renin angiotensin system [86]. The use of lisinopril initiated treatment vs chlorthalidone in patients of African ethnicity was associated with a relative greater risk of morbidity: combined CHD (1.15 [1.02; 1.30]), combined CVD (1.19 $[1.09 ; 1.30])$, stroke $1.40[1.17 ; 1.68]$, angina 1.24 [1.07; 1.44]. Heart failure risk was lower with chlorthalidone [86]. No data were provided for lisinopril vs amlodipine.

In line with these findings with ACE inhibitors, the LIFE study showed that losartan-initiated therapy was superior to atenolol-initiated therapy in reducing stroke risk in hypertensive patients of European descent. However, among patients of African descent, losartan-initiated treatment was associated with a nearly significant increase in stroke events compared with atenolol unadjusted hazard ratio, $1.99[1.00 ; 3.98]$ [85], similar to the findings of the primary outcome, a composite outcome including stroke $[17,73]$. In addition, the risk for sudden death was $97 \%$ higher in patients of African descent in the LIFE trial, with, at this relatively small sample size $(n=533)$ a trend towards increased risk with losartan [87]. These data indicate that therapy initiated with blockers of the reninangiotensin-system is associated with a greater cardiovascular morbidity and mortality in patients of African ethnicity.

We defined subgroups based on gender and based on geographical location for morbidity and mortality outcomes. However, morbidity and mortality trials were conducted in the USA only or included only a very small number of non-USA patients (Table 2). The SHEP trial's outcome for men and women is discussed above, with diuretics not significantly different from placebo in preventing stroke in African ethnicity men. In ALLHAT, men of African descent had the highest absolute stroke risk (mean 6 year rate/100 patients 7.73, 5.90, 5.81, and 5.90, in African ethnicity men, women, and white men, women respectively) and the highest stroke risk with lisinopril of all sex-ethnic groups (6 year rate/100 patients for lisinopril 9.41, 7.25, 5.32, and 5.59, respectively) [88]. Furthermore, pharmacogenetics outcomes differed by gender in the AASK trial, only women randomized to a usual blood pressure goal (mean arterial pressure 102-107 $\mathrm{mmHg}$ ), and with an A allele at CYP3A4 A392G, were more likely to reach a target MAP of $107 \mathrm{mmHg}$ [adjusted hazard ratio of AA/AG compared to GG 3.41 (95\% CI 1.20-9.64; $P=0.02)]$. Among participants randomized to a lower MAP goal, men and women with the $\mathrm{C}$ allele at $C Y P 3 A 4$ T16090C were more likely to reach the target MAP of $107 \mathrm{mmHg}$ [adjusted hazard ratio 2.04 (95\% CI 1.17-3.56; $P=0.01)]$. In addition, the polymorphisms Arg65Leu, Ala142Val, and Ala486Val of the G proteincoupled receptor kinase gene, GRK4, were studied in the 
AASK Study. Only in men randomized to the usual blood pressure goal (mean arterial pressure $102-107 \mathrm{mmHg}$ ), the adjusted "hazard" ratio to reach the goal blood pressure with metoprolol was 1.54 (95\% CI 1.11-2.44; $P<0.01$ ) with Ala142Val. There was no association between GRK4 polymorphisms and blood pressure response to metoprolol in women [16].

Compliance data by ethnicity were only available for the AASK study. Based on self-reported data and pill counts, $23 \%$ of the patients had at least one noncompliant event, non-adherence events (\%) per patient year respectively were 7.7, 6.6, and 7.1 for metoprolol, ramipril and amlodipine [74-76].

As approaches to the management of cardiovascular disease risk need to integrate assessment and treatment of several risk factors, we describe the outcome of the lipid lowering treatment arm of the ALLHAT trial (ALLHATLLT) [89]. Patients of African ethnicity have been underrepresented in prior trials addressing the effects of cholesterol lowering. Participants treated for hypertension in ALLHAT were eligible for inclusion in ALLHAT-LLT when fasting LDL-C levels were $120-189 \mathrm{mg} / \mathrm{dL}$ $(3.1-4.9 \mathrm{mmol} / \mathrm{L})$ or $100-129 \mathrm{mg} / \mathrm{dL}(2.6-3.3 \mathrm{mmol} / \mathrm{L})$ respectively for those with and without known coronary heart disease. The primary outcome was all-cause mortality in patients randomized to pravastatin $20-40 \mathrm{mg}$ vs usual care (respectively $n=1769$ vs $n=1722$ African ethnicity patients). Vigorous cholesterol lowering therapy was discouraged in the usual care group, therefore the majority of these patients did not receive lipid lowering drugs $(90 \%$ in the second year to $72 \%$ in the sixth year of the trial). There was no difference in the primary outcome of all-cause mortality between pravastatin and usual care (RR for African ethnicity patients 1.01 [0.85-1.19]). In other outcomes, the relative risk for atherosclerotic coronary heart disease events with pravastatin was lower in patients of African descent than in other patients (RR 0.73 [0.58-0.92] vs $1.02[0.81-1.28] ; P=0.03)$. However, there was a significantly greater stroke risk with pravastatin in patients of African descent (RR 1.12 vs 0.74 in other patients, confidence intervals not reported; $P=0.03$ ). As a result, there was no significant effect of pravastatin treatment on combined cardiovascular disease outcomes in hypertensive patients of African ethnicity [89].

\section{Patients of South Asian ethnicity}

With electronic searches (November 2015) we retrieved 1578 papers. We additionally retrieved three trials with hand search, which were not eligible for inclusion. Sixteen randomized controlled trials were included, with blood pressure as the main outcome. Only one trial was placebo controlled, other trials assessed monotherapy with a drug from one drug
Fig. 2 Effect of different antihypertensive drugs on blood pressure in patients of African ethnicity. a Systolic blood pressure. b Diastolic blood pressure. a, b Our previous review [17] was updated (November 2015). Except for two nebivolol studies [46, 53], no new trials with single drugs vs placebo and blood pressure outcomes were retrieved. Random, random-effects model. Results are reported as weighted mean differences in reduction of systolic and diastolic blood pressure $(\mathrm{mmHg})$ from baseline to endpoint with the use of different antihypertensive drugs compared to placebo. Squares are weighted mean differences in reduction of SBP/DBP $(\mathrm{mmHg})$. The size of the squares represents study weight, and horizontal lines represent $95 \%$ CIs. Arrowheads depict data outside the scale. When a study provided only the placebo-drug difference, we entered a "nil" for placebo results. Results for Materson and colleagues' study and Weir and colleagues' study are weighted means of older and younger people and patients receiving a high and a low-salt diet, respectively. Black diamonds are pooled estimates. Results for calcium-channel blockers were not pooled because the size of the effect was heterogeneous. $A B C$ Association of Black Cardiologists, TAIM Trial of Antihypertensive Interventions and Management, TOMHS Treatment of Mild Hypertension Study, TROPHY Treatment in Obese Patients with Hypertension [36-66]

class vs a drug from another class. We did not include trials that only compared drugs within one antihypertensive drug class. The 16 included trials (Fig. 3; Table 3) were 4 weeks to 9 months duration (median 8 weeks), containing original data of 6 classes of antihypertensive drugs in 1719 South Asian hypertensive patients without a history of, or current cardiovascular events ( $n=37$ diabetics) [55, 90-104].

Blood pressure at inclusion was generally between 140 and $180 \mathrm{mmHg}$ systolic, and 90 to $110 \mathrm{mmHg}$ diastolic. Most trials were conducted in India. The methodological quality of the trials was less than in the African patients, with the Jadad scores between 1 and 4 (median 2). No trial had a Jadad score of 5, and only 2 were double blinded. Most trials reported side effects and drop outs, but intention-to-treat analysis was used in only one (Table 3).

There were no significant differences between drug classes in blood pressure-lowering efficacy, as analysed per comparison presented in the trial data [35], (data not shown). Calculation of the blood pressure lowering effect per drug class was hampered by the limited data and heterogeneity that could not be well accounted for (partly due the small number of trials). However, South Asians ethnicity patients represent a population subgroup where the average effect is of clinical relevance. Therefore, we allowed for heterogeneity in an a posteriori analysis, and used the random effects model to calculate the inverse variance-weighted mean blood pressure lowering effect of the different drug classes (Table 4) [35].

Other effects described included that lisinopril reduced micro-albuminuria ( -33 vs $-10 \%$ in amlodipine) [95], while diuretics and beta-adrenergic blockers were reported to have the well-known metabolic side effects on lipid and glucose metabolism. Non-diuretic, non-beta-adrenergic 


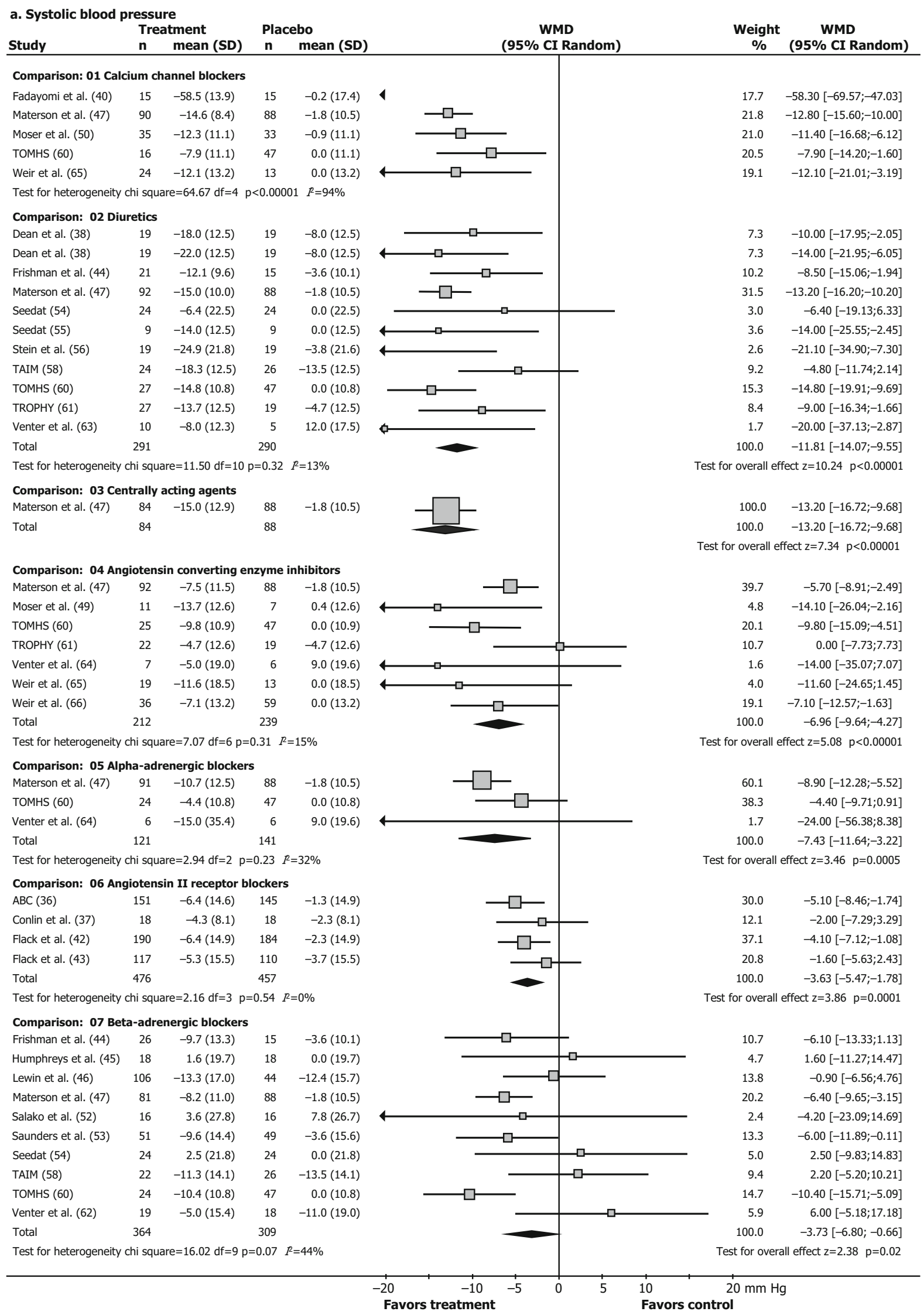




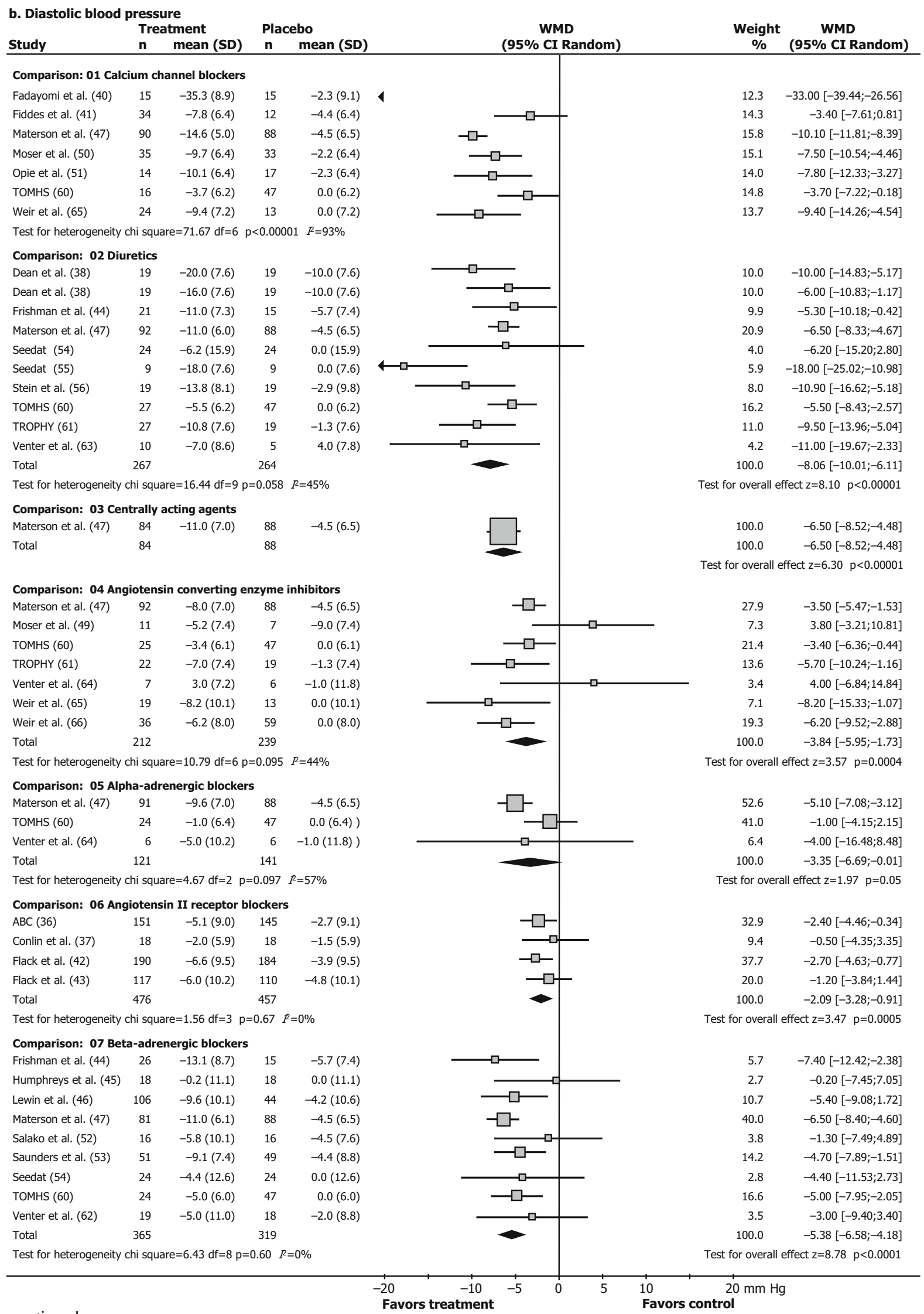

Fig. 2 continued

$$
\begin{array}{lll}
\text { Favors treatment } & \text { Favors control }
\end{array}
$$




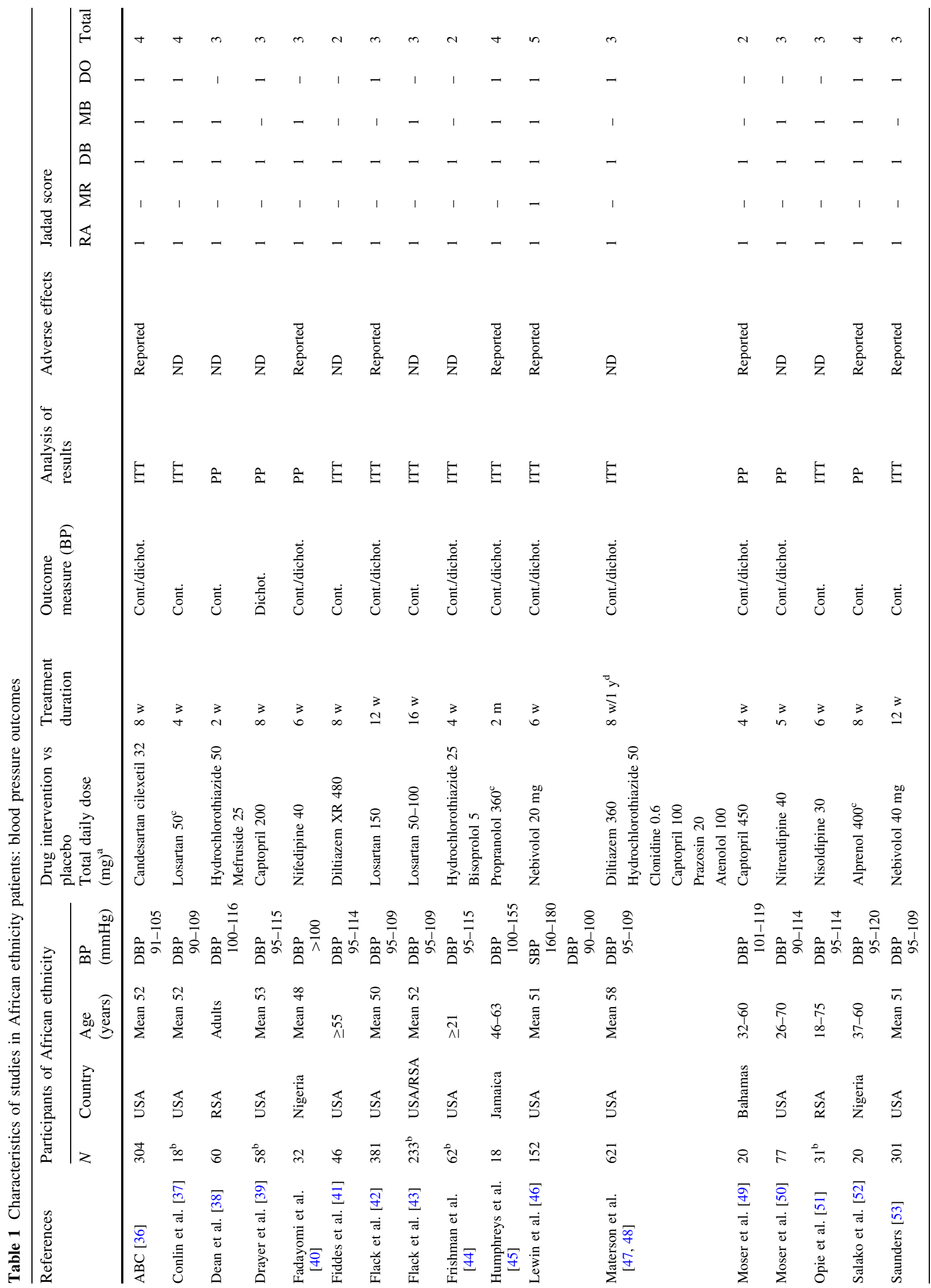




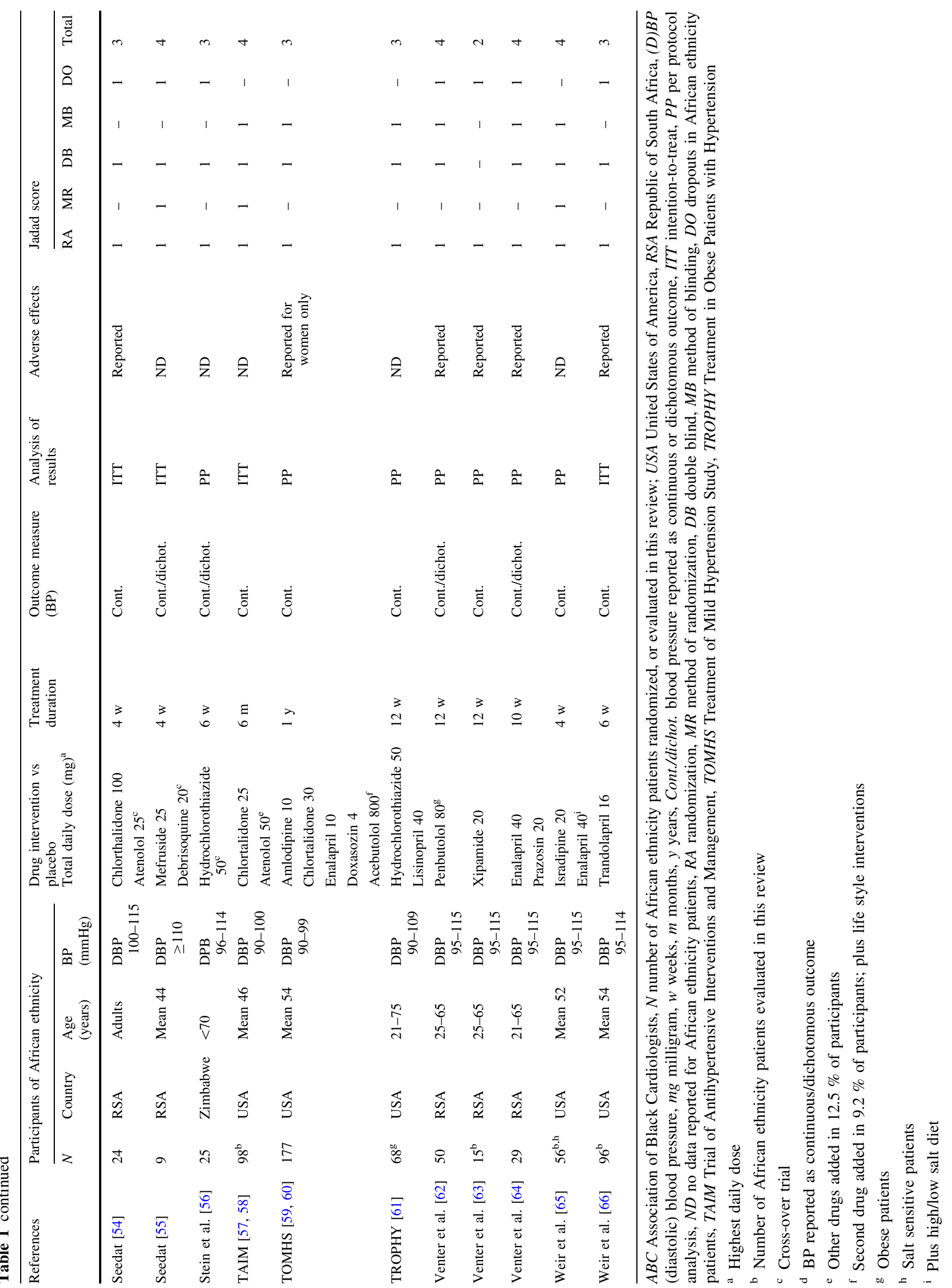




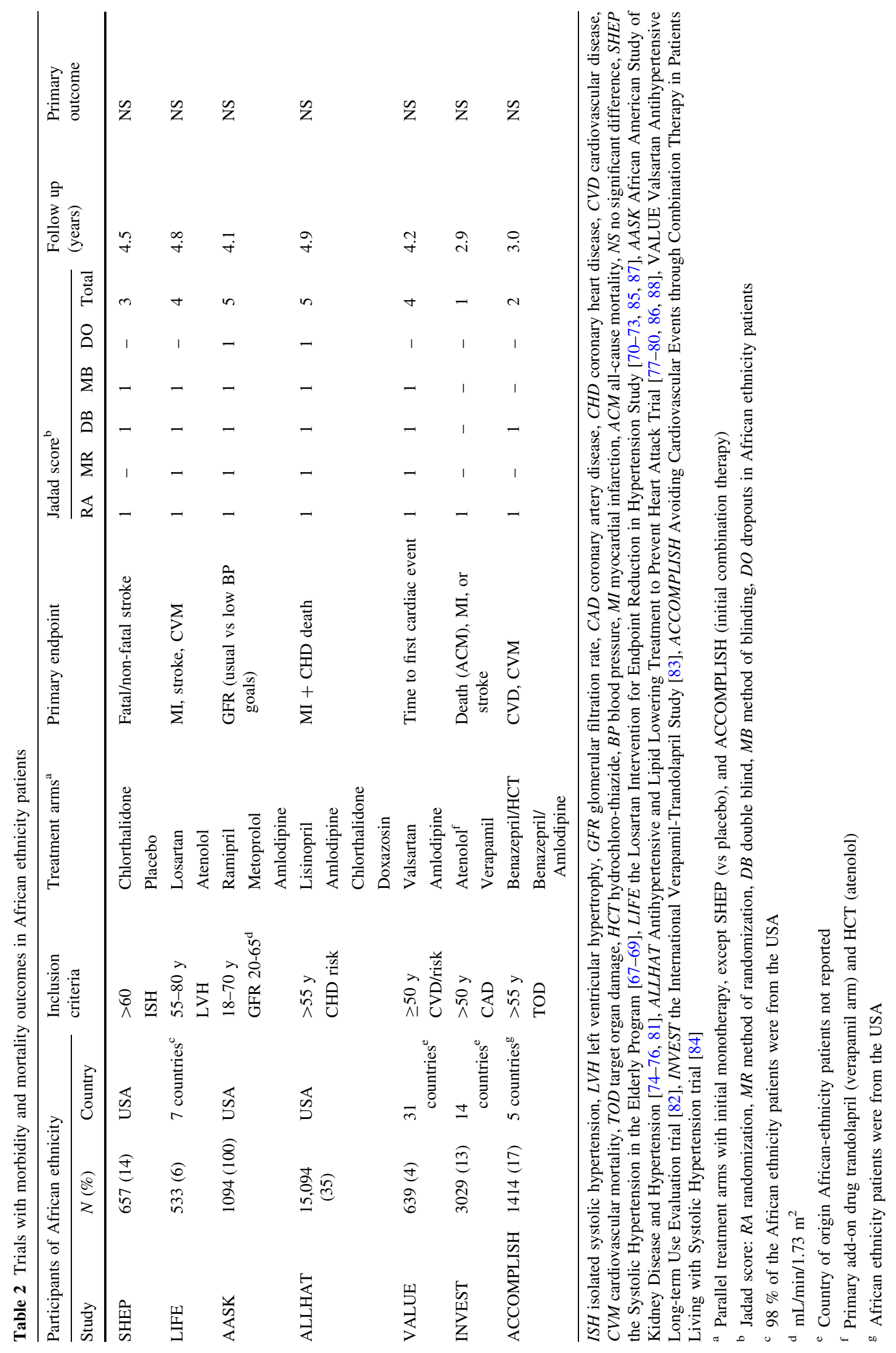


Fig. 3 Trial flow: patients of South-Asian ethnicity. Asterisk indicate that we included randomized controlled trials (RCT's) with single drug therapy vs placebo, or vs single drug from another antihypertensive drug class for blood pressure outcomes (at least 2 weeks duration); and with single drug-based or combination therapy for morbidity and mortality outcomes of at least 1 year duration, providing original quantitative data in hypertensive South-Asian adult men or nonpregnant women. Most excluded papers were not an RCT; and of the RCT's retrieved, most were either not an RCT in hypertensives, or an RCT's in other ethnic groups, an RCTs with combination therapy, a dose finding trial, trials comparing two drugs within one drug class, or trials of antihypertensive drugs vs non-drug therapy or phytotherapy $(n=1525)$

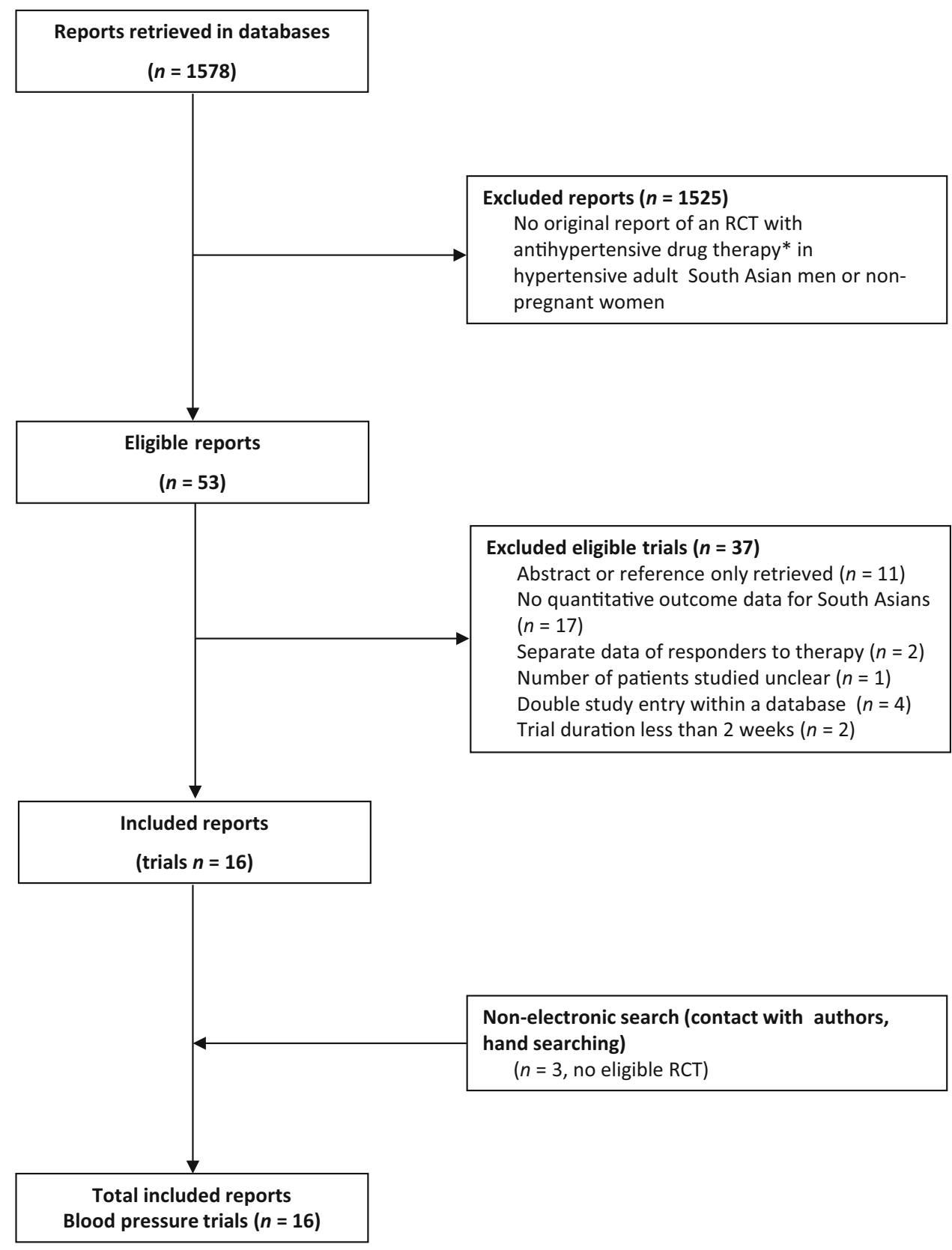

blocking drugs had a better metabolic profile $[97,99,101]$. There were no separate data provided based on gender, and no trials with morbidity and mortality outcomes.

\section{Discussion}

The WHO Global Monitoring Framework has set a target of $25 \%$ reduction in premature mortality from non-communicable diseases by 2025 , including a $25 \%$ reduction in the prevalence of hypertension [105]. Hypertension is the main cause of cardiovascular disease and death across populations worldwide [106], and if the targets are met, premature CVD deaths are projected to be reduced to 5.7 million as a result of a $26 \%$ reduction for men and a $23 \%$ reduction for women [107]. Globally, decreasing the prevalence of hypertension accounts for the largest risk reduction, followed by a reduction in tobacco smoking for men and obesity for women [107]. Since hypertension may differ in age of onset, severity, and response to treatment in different ethnic groups, the increasing ethnic diversity of the European population creates a need for adjusted guidelines to adequately reduce risk factor level in all ethnic groups.

Antihypertensive drugs are the first cardiovascular therapy for which there was wide recognition of 


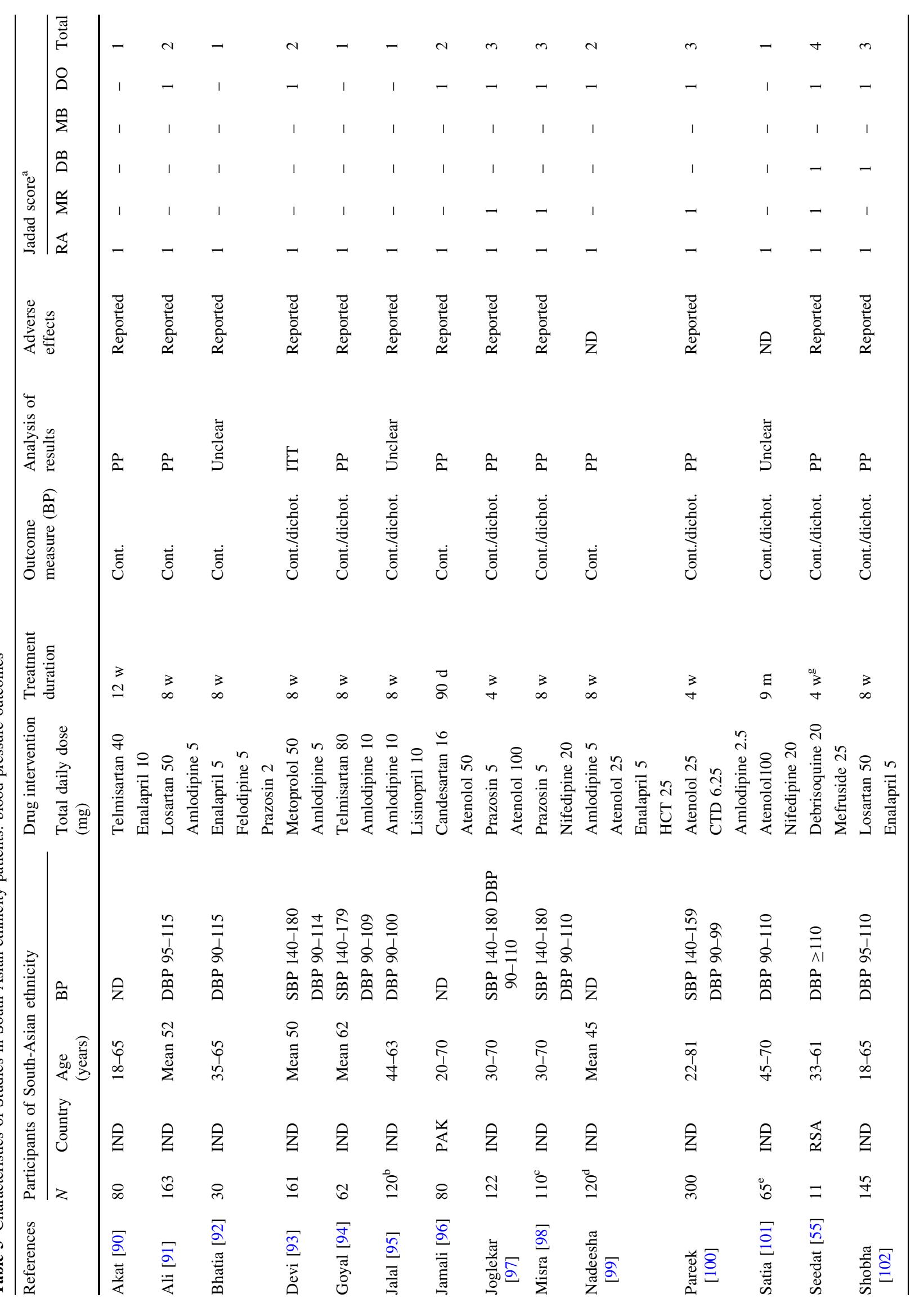




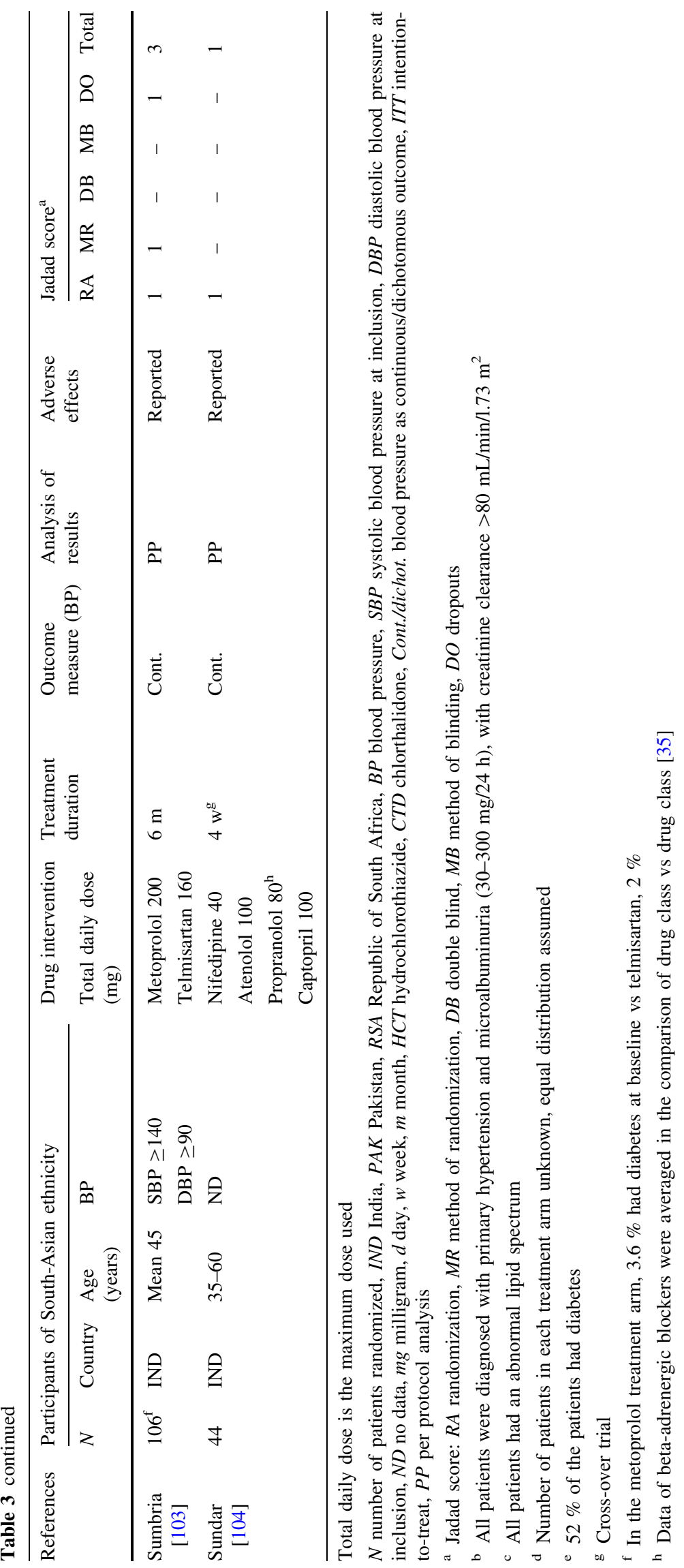


Table 4 Systolic, diastolic, and target blood pressure by drug class in South Asian patients

\begin{tabular}{lllll}
\hline Drug class & Systolic BP, mean reduction $[\mathrm{CI}]$ & Target SBP $(\%)$ & Diastolic BP, mean reduction $[\mathrm{CI}]$ & Target DBP $(\%)$ \\
\hline Calcium blockers & $-19.08[-22.75 ;-15.42]$ & $52-88$ & $-10.81[-11.58,-10.04]$ & $46-82$ \\
Diuretics & $-13.58[-24.40 ;-2.76]$ & ND & $-9.75[-16.30 ;-3.19]$ & $0^{\mathrm{a}}$ \\
ACE-inhibitors & $-22.51[-24.73 ;-20.29]$ & ND & $-12.78[-16.61 ;-8.95]$ & 44 \\
Alpha-blockers & $-10.41[-19.48 ;-1.34]$ & $39-44$ & $-10.06[-13.78 ;-6.35]$ & $0-65^{\mathrm{a}}$ \\
ATII-blockers & $-22.63[-28.55 ;-16.70]$ & 80 & $-14.88[-16.49 ;-13.27]$ & $59-97$ \\
Beta-blockers & $-21.11[-26.44 ;-15.77]$ & 76 & $-13.95[-16.67 ;-11.23]$ & $74-77$
\end{tabular}

Depicted are inverse-variance weighted means (CI $95 \%$ confidence intervals) of blood pressure reduction (mmHg) per drug type, and range of target blood pressure achievement (\%) in South Asian hypertensive patients. Evidence from randomized controlled trials of antihypertensive monotherapy $(n=16 ;[55,90-104])$. Target blood pressure $(n=9$ trials) $[55,93-95,97,98,100-102]$ was defined by authors, usually SBP $<140 \mathrm{mmHg}$; DBP $<90 \mathrm{mmHg}$

Calcium blockers calcium channel blockers, ACE-inhibitors angiotensin converting enzyme inhibitors, Alpha blockers alpha-adrenergic blockers, ATII blockers angiotensin II receptor blockers, beta-blockers beta-adrenergic blockers, ND no data

a Trials typically had an inclusion baseline DBP $<115 \mathrm{mmHg}$ (Table 3). In the only trial with baseline DPB $>110$, no patient reached diastolic treatment goal with diuretics or alpha blockers [55]. No data were retrieved on centrally acting agents. There was no significant difference in blood pressure lowering effect of different drug types, using comparisons as reported in the trials

differences in clinical efficacy related to ethno-geographical ancestry [16]. Patients of African descent as a group respond better to calcium blockers and diuretics, while the response to $\beta$-adrenergic blockade and inhibition of the angiotensin converting enzyme is attenuated [16, 17]. Currently, self-identified ethno-geographic ancestry is the best available predictor of this differential blood pressure lowering response to antihypertensive drugs [16]. As in African patients, South Asians also develop hypertension at an earlier age, with more end organ damage, but there are no known differences in the blood pressure lowering response to antihypertensive drugs, and despite the greater mortality, to our knowledge there are no trials in South Asians with morbidity and mortality outcomes.

The existing evidence provides ample evidence of higher risk of premature cardiovascular mortality in South Asian and African ancestry groups [3-22]. However, to better quantify this risk and develop more effective guidelines, we need to improve risk assessment, and use risk scores validated for ethnic minorities [108, 109]. To this end, we urgently need European morbidity and mortality outcome data for these ethnic groups, as these are likely to differ from the American and Canadian situation, where far higher treatment and control rates for hypertension are reached $[18,110]$. Thus, the risk of premature mortality in South Asian and African ancestry groups in Europe is probably underestimated [5]. Although new approaches to estimate risk in these groups have been launched [108, 109], there is still a need for data to support these.

Also, we need data on whether lower thresholds to start treatment and lower therapeutic goal blood pressures need to be applied [111]. The Systolic Blood Pressure Intervention (SPRINT) trial indicates a lower cardiovascular morbidity and mortality within 3 years with a systolic goal blood pressure $<120$ vs $<140 \mathrm{mmHg}$. However, this difference does not reach statistical significance in the subgroup of African ethnicity patients, with a relatively small sample size and a substantially lower mean age $(-5$ years) in this subgroup [111]. The International Society for Hypertension in Blacks [112] advises the initiation of treatment in patients of African ethnicity from 135 systolic or $85 \mathrm{mmHg}$ diastolic blood pressure, and similar approaches have been suggested in South Asians [113].

The strength of this work is that we systematically review the available evidence of antihypertensive drug treatment with monotherapy for uncomplicated hypertension, and combination therapy for morbidity and mortality outcomes in hypertensive patients of African and South Asian ethnicity. The aggregated evidence should facilitate guideline development to reduce premature adverse outcomes in these high-risk population subgroups, but many questions remain. We are not well informed regarding the socio-economic circumstances of trial participants, which may have affected treatment failure [18]. Also, the trials are conducted in the USA, Africa and India mainly, and data on European ethnic populations are scarce. In addition, trials rarely report outcomes for men and women separately. Finally, there are no available quantitative data on antihypertensive therapy to reduce morbidity and mortality in South Asians, and newer, non-drug techniques for blood pressure lowering in therapy-resistant hypertension such as renal denervation are of unknown efficacy in South Asians, while in African ethnicity patients there was no significant difference with a sham procedure [114].

However, since there are ample effective drugs available, reducing hypertension and risk of end organ damage in these ethnic groups may predominantly involve different health management strategies. Public health approaches have been suggested to combat hypertension in all ethnic groups, with better models of screening, delivery of care 
(nurse-based, door-step care), the use of a registry to treat and follow all hypertensives, and initial low dose combination therapy to increase compliance and blood pressure lowering efficacy, while reducing adverse effects [115, 116]. Hypertensive patients of African or South Asian descent should benefit from these more aggressive approaches.

In summary, hypertension in persons of African or South Asian ethnicity occurs more frequently, and is associated with more therapy failure and more severe and earlier end organ damage. European guidelines for cardiovascular risk management should take this high risk into account. Persons of African or South Asian ethnicity need to be screened at a younger age, and treatment should potentially start at lower thresholds with early use of combination therapy and intensive treatment monitoring to reduce the high premature mortality.

\section{Acknowledgments None.}

\section{Compliance with ethical standards}

Conflict of interest The authors declare that they have no conflict of interest.

Statement of human and animal rights All procedures performed in studies involving human participants were in accordance with the ethical standards of the institutional and/or national research committee and with the 1964 Helsinki declaration and its later amendments or comparable ethical standards.

Informed consent Informed consent was not required for this retrospective study.

Open Access This article is distributed under the terms of the Creative Commons Attribution 4.0 International License (http://crea tivecommons.org/licenses/by/4.0/), which permits unrestricted use, distribution, and reproduction in any medium, provided you give appropriate credit to the original author(s) and the source, provide a link to the Creative Commons license, and indicate if changes were made.

\section{References}

1. Eurostat (2015) http://ec.europa.eu/eurostat/statistics-explained/ index.php/Migration_and_migrant_population_statistics/nl. Accessed 11 Nov 2015

2. Nichols M, Townsend N, Luengo-Fernandez R, Leal J, Gray A, Scarborough P, Rayner M (2012) European cardiovascular disease statistics 2012. Brussels, European Society of Cardiology, Sophia Antipolis, European Heart Network

3. Gu Q, Burt VL, Paulose-Ram R, Yoon S, Gillum RF (2008) High blood pressure and cardiovascular disease mortality risk among US adults: the third National Health and Nutrition Examination Survey mortality follow-up study. Ann Epidemiol 18:302-309

4. Martins D, Tareen N, Ogedegbe G, Pan D, Norris K (2008) The relative risk of cardiovascular death among racial and ethnic minorities with metabolic syndrome: data from the NHANES-II mortality follow-up. J Natl Med Assoc 100:565-571

5. Cappuccio FP, Oakeshott P, Strazzullo P, Kerry SM (2002) Application of Framingham risk estimates to ethnic minorities in United Kingdom and implications for primary prevention of heart disease in general practice: cross sectional population based study. BMJ 325:1271

6. Brewster LM, Stronks K, van Montfrans G (2009) Lipid profile in a triethnic population in the Netherlands: the Sunset Study. J Hypertens 27:S324

7. Dekker LH, Nicolaou M, van der A DL, Busschers WB, Brewster LM, Snijder MB, Stronks K, van Valkengoed IG (2013) Sex differences in the association between serum ferritin and fasting glucose in type 2 diabetes among South Asian Surinamese, African Surinamese, and ethnic Dutch: the population-based SUNSET study. Diabetes Care 36:965-971

8. Brewster LM, Mairuhu G, Bindraban NR, Koopmans RP, Clark JF, van Montfrans GA (2006) Creatine kinase activity is associated with blood pressure. Circulation 114:2034-2039

9. Karthikeyan G, Teo KK, Islam S, McQueen MJ, Pais P, Wang $\mathrm{X}$, Sato H, Lang CC, Sitthi-Amorn C, Pandey MR, Kazmi K, Sanderson JE, Yusuf S (2009) Lipid profile, plasma apolipoproteins, and risk of a first myocardial infarction among Asians: an analysis from the INTERHEART Study. J Am Coll Cardiol 53:244-253

10. Okin PM, Kjeldsen SE, Dahlöf B, Devereux RB (2011) Racial differences in incident heart failure during antihypertensive therapy. Circ Cardiovasc Qual Outcomes 4:157-164

11. Joshi P, Islam S, Pais P, Reddy S, Dorairaj P, Kazmi K, Pandey MR, Haque S, Mendis S, Rangarajan S, Yusuf S (2007) Risk factors for early myocardial infarction in South Asians compared with individuals in other countries. JAMA 297:286-294

12. Jolly S, Vittinghoff E, Chattopadhyay A, Bibbins-Domingo K (2010) Higher cardiovascular disease prevalence and mortality among younger blacks compared to whites. Am J Med 123:811-818

13. Opie LH, Seedat YK (2005) Hypertension in sub-Saharan African populations. Circulation 112:3562-3568

14. Haan YC, van Montfrans GA, Brewster LM (2015) The high creatine kinase phenotype is hypertension- and obesity-prone. J Clin Hypertens 17:322

15. Eastwood SV, Tillin T, Chaturvedi N, Hughes AD (2015) Ethnic differences in associations between blood pressure and stroke in South Asian and European men. Hypertension 66:481-488

16. Brewster LM, Seedat YK (2013) Why do hypertensive patients of African ancestry respond better to calcium blockers and diuretics than to ACE inhibitors and $\beta$-adrenergic blockers? A systematic review. BMC Med 11:141

17. Brewster LM, van Montfrans GA, Kleijnen J (2004) Systematic review: antihypertensive drug therapy in black patients. Ann Intern Med 141:614-627

18. Oudman I, Kewalbansingh PV, van Valkengoed I, Zwinderman AH, Clark JF, van Montfrans GA, Brewster LM (2013) Creatine kinase is associated with failure of hypertension treatment. J Hypertens 31:1025-1031

19. Kramer H, Han C, Post W, Goff D, Diez-Roux A, Cooper R, Jinagouda S, Shea S (2004) Racial/ethnic differences in hypertension and hypertension treatment and control in the multiethnic study of atherosclerosis (MESA). Am J Hypertens 17:963-970

20. Kizer JR, Arnett DK, Bella JN, Paranicas M, Rao DC, Province MA, Oberman A, Kitzman DW, Hopkins PN, Liu JE, Devereux RB (2004) Differences in left ventricular structure between black and white hypertensive adults: the Hypertension Genetic Epidemiology Network study. Hypertension 43:1182-1188 
21. Spencer CG, Beevers DG, Lip GY (2004) Ethnic differences in left ventricular size and the prevalence of left ventricular hypertrophy among hypertensive patients vary with electrocardiographic criteria. J Hum Hypertens 18:631-636

22. Mohan V, Seedat YK, Pradeepa R (2013) The rising burden of diabetes and hypertension in southeast asian and african regions: need for effective strategies for prevention and control in primary health care settings. Int J Hypertens 2013:409083

23. Parati G, Steptoe A (2004) Stress reduction and blood pressure control in hypertension: a role for transcendental meditation? J Hypertens 22:2057-2060

24. Sacks FM, Svetkey LP, Vollmer WM, Appel LJ, Bray GA, Harsha D, Obarzanek E, Conlin PR, Miller ER 3rd, SimonsMorton DG, Karanja N, Lin PH, DASH-Sodium Collaborative Research Group (2001) Effects on blood pressure of reduced dietary sodium and the Dietary Approaches to Stop Hypertension (DASH) diet. DASH-Sodium Collaborative Research Group. N Engl J Med 344:3-10

25. Graudal N, Jürgens G (2015) The blood pressure sensitivity to changes in sodium intake is similar in Asians, Blacks and Whites. An analysis of 92 randomized controlled trials. Front Physiol 6:157

26. Chan Q, Stamler J, Elliott P (2015) Dietary factors and higher blood pressure in African-Americans. Curr Hypertens Rep 17:10

27. Jessani S, Hatcher J, Chaturvedi N, Jafar TH (2008) Effect of low vs. high dietary sodium on blood pressure levels in a normotensive Indo-Asian population. Am J Hypertens 21:1238-1244

28. Patki PS, Singh J, Gokhale SV, Bulakh PM, Shrotri DS, Patwardhan B (1990) Efficacy of potassium and magnesium in essential hypertension: a double-blind, placebo controlled, crossover study. BMJ 301:521-523

29. Subramanian H, Soudarssanane MB, Jayalakshmy R, Thiruselvakumar D, Navasakthi D, Sahai A, Saptharishi L (2011) Nonpharmacological Interventions in hypertension: a communitybased cross-over randomized controlled trial. Indian J Community Med 36:191-196

30. Selvamurthy W, Sridharan K, Ray US, Tiwary RS, Hegde KS, Radhakrishan U, Sinha KC (1998) A new physiological approach to control essential hypertension. Indian J Physiol Pharmacol 42:205-213

31. Graudal N, Jürgens G, Baslund B, Alderman MH (2014) Compared with usual sodium intake, low- and excessive-sodium diets are associated with increased mortality: a meta-analysis. Am J Hypertens 27:1129-1137

32. Kalogeropoulos AP, Georgiopoulou VV, Murphy RA, Newman AB, Bauer DC, Harris TB, Yang Z, Applegate WB, Kritchevsky SB (2015) Dietary sodium content, mortality, and risk for cardiovascular events in older adults: the Health, Aging, and Body Composition (Health ABC) Study. JAMA Intern Med 175:410-419

33. US Department of Agriculture and US Department of Health and Human Services (2010) Dietary guidelines for Americans, 2010, 7th edn. US Government Printing Office, Washington

34. Park IU, Taylor AL (2007) Race and ethnicity in trials of antihypertensive therapy to prevent cardiovascular outcomes: a systematic review. Ann Family Med 5:444-452

35. Higgins JPT, Green S (2011) (eds) Cochrane handbook for systematic reviews of interventions version 5.1.0 [updated March 2011]. The Cochrane Collaboration

36. Association of Black Cardiologists (ABC) Candesartan Study Group (2000) Evaluation of candesartan cilexetil in black patients with systemic hypertension: the ABC Trial. Heart Dis 2:392-399

37. Conlin PR, Erlinger TP, Bohannon A, Miller ER 3rd, Appel LJ, Svetkey LP, Moore TJ (2003) The DASH diet enhances the blood pressure response to losartan in hypertensive patients. Am J Hypertens 16:337-342
38. Dean G, Louw S, Hersch C, Kirsten HO, Brereton DN, Finnemore L, Dewar J (1971) A double-blind trial in hypertension comparing Baycaron (FBA 1500), hydrochlorothiazideand placebo. S Afr Med J 45:323

39. Drayer JI, Weber MA (1983) Monotherapy of essential hypertension with a converting-enzyme inhibitor. Hypertension 5:108-113

40. Fadayomi MO, Akinroye KK, Ajao RO, Awosika LA (1986) Monotherapy with nifedipine for essential hypertension in adult blacks. J Cardiovasc Pharmacol 8:466-469

41. Fiddes R, Heym H, Hilty W, Lewin AJ, Codispoti J, McNally C, Stokes A, Gilderman L (1994) Blood pressure control with diltiazem XR, a novel extended-release formulation of diltiazem $\mathrm{HCl}$, in mature and elderly hypertensive patients. Clin Ther $16: 209-221$

42. Flack JM, Saunders E, Gradman A, Kraus WE, Lester FM, Pratt JH, Alderman M, Green S, Vargas R, Espenshade M, Ceesay P, Alexander J Jr, Goldberg A (2001) Antihypertensive efficacy and safety of losartan alone and in combination with hydrochlorothiazide in adult African Americans with mild to moderate hypertension. Clin Ther 23:1193-1208

43. Flack JM, Oparil S, Pratt JH, Roniker B, Garthwaite S, Kleiman JH, Yang Y, Krause SL, Workman D, Saunders E (2003) Efficacy and tolerability of eplerenone and losartan in hypertensive black and white patients. J Am Coll Cardiol 41:1148-1155

44. Frishman WH, Burris JF, Mroczek WJ, Weir MR, Alemayehu D, Simon JS, Chen SY, Bryzinski BS (1995) First-line therapy option with low-dose bisoprolol fumarate and low-dose hydrochlorothiazide in patients with stage I and stage II systemic hypertension. J Clin Pharmacol 35:182-188

45. Humphreys GS, Delvin DG (1968) Ineffectiveness of propranolol in hypertensive Jamaicans. Br Med J 2:601-603

46. Lewin A, Punzi H, Luo X, Stapff M (2013) Nebivolol monotherapy for patients with systolic stage II hypertension: results of a randomized, placebo-controlled trial. Clin Ther $35: 142-152$

47. Materson BJ, Reda DJ, Cushman WC, Massie BM, Freis ED, Kochar MS, Hamburger RJ, Fye C, Lakshman R, Gottdiener J, Ramirez EA, Henderson WG (1993) Single-drug therapy for hypertension in men. A comparison of six antihypertensive agents with placebo. The Department of Veterans Affairs Cooperative Study Group on Antihypertensive Agents. N Engl J Med 328:914-921

48. Materson BJ, Reda DJ, Cushman WC (1995) Department of Veterans Affairs single-drug therapy of hypertension study. Revised figures and new data. Am J Hypertens 8:189-192

49. Moser M, Lunn J (1982) Responses to captopril and hydrochlorothiazide in black patients with hypertension. Clin Pharmacol Ther 32:307-312

50. Moser M, Lunn J, Nash DT, Burris JF, Winer N, Simon G, Vlachakis ND (1984) Nitrendipine in the treatment of mild to moderate hypertension. J Cardiovasc Pharmacol 6(Suppl 7):S1085-S1089

51. Opie LH, Muller FO, Myburgh DP, Rosendorff C, Sareli P, Seedat YK, Weich DJ, Luus HG (1997) Efficacy and tolerability of nisoldipine coat-core formulation in the treatmentof essential hypertension: the South African Multicenter ANCHOR Study. Am J Hypertens 10:250-260

52. Salako LA, Falase AO, Aderounmu AF (1979) Placebo-controlled, double-blindclinical trial of alprenolol in African hypertensive patients. Curr Med Res Opin 6:358-363

53. Saunders E, Smith WB, DeSalvo KB, Sullivan WA (2007) The efficacy and tolerability of nebivolol in hypertensive African American patients. J Clin Hypertens 9:866-875

54. Seedat YK (1980) Trial of atenolol and chlorthalidone for hypertension in black South Africans. Br Med J 281:1241-1243 
55. Seedat YK (1980) An evaluation of debrisoquine and mefruside in the treatment of hypertension in African and Indian patients. Curr Med Res Opin 7:68-72

56. Stein CM, Neill P, Kusemamuriwo T (1992) Antihypertensive effects of low doses of hydrochlorothiazide in hypertensive black Zimbabweans. Int J Cardiol 37:231-235

57. Davis BR, Blaufox MD, Hawkins CM, Langford HG, Oberman A, Swencionis C, Wassertheil-Smoller S, Wylie-Rosett J, Zimbaldi N (1989) Trial of antihypertensive interventions and management. Design, methods, and selected baseline results. Control Clin Trials 10:11-30

58. Wassertheil-Smoller S, Davis BR, Oberman AS, Blaufox MD, Langford HG, Wylie-Rosett J, Hawkins M, Zimbaldi N (1991) The Taim Study: sex-race differences in effects of diet and drugs on cardiovascular risk. Cardiovasc Risk Factors 1:3-11

59. Neaton JD, Grimm RH Jr, Prineas RJ, Stamler J, Grandits GA, Elmer PJ, Cutler JA, TOMHS Research Group (1993) Treatment of Mild Hypertension Study. Final results. Treatment of Mild Hypertension Study Research Group. JAMA 270:713-724

60. Grimm RH, Grandits GA, Flack JM (1997) Are black and white hypertensives really different? ABC Digest Urban Cardiol 4:10-16

61. Reisin E, Weir MR, Falkner B, Hutchinson HG, Anzalone DA, Tuck ML, Treatment in Obese Patients with Hypertension (TROPHY) Study Group (1997) Lisinopril versus hydrochlorothiazide in obese hypertensive patients: a multicenter placebo-controlled trial. Hypertension 30:140-145

62. Venter CP, Joubert PH, Venter HL, Muntingh GL, du Plooy WJ (1990) Penbutolol in the treatment of mild to moderate essential hypertension in black South Africans. J Clin Pharmacol 30:533-537

63. Venter CP, Muntingh GL, Venter HL, du Plooy WJ (1991) The effect of xipamide on mild-moderate hypertension in black South Africans-results of a clinical trial. Med Sci Res 19:217-218

64. Venter CP, Venter HL, Muntingh GL (1991) The effect of enalapril and prazosin on mild to moderate hypertension in black South Africans. S Afr Med J 80:324-326

65. Weir MR, Chrysant SG, McCarron DA, Canossa-Terris M, Cohen JD, Gunter PA, Lewin AJ, Mennella RF, Kirkegaard LW, Hamilton JH, Weinberger MH, Weder AB (1998) Influence of race and dietary salt on the antihypertensive efficacy of an angiotensin-converting enzyme inhibitor or a calcium channel antagonist in salt-sensitive hypertensives. Hypertension 31:1088-1096

66. Weir MR, Saunders E (1998) Renin status does not predict the anti-hypertensive response to angiotensin-converting enzyme inhibition in African-Americans. Trandolapril Multicenter Study Group. J Hum Hypertens 12:189-194

67. The Systolic Hypertension in the Elderly Program (SHEP) Cooperative Research Group (1988) Rationale and design of a randomized clinical trial on prevention of stroke in isolated systolic hypertension. J Clin Epidemiol 41:1197-1208

68. SHEP Cooperative Research Group (1991) Prevention of stroke by antihypertensive drug treatment in older persons with isolated systolic hypertension. Final results of the Systolic Hypertension in the Elderly Program (SHEP). JAMA 265:3255-3264

69. The Systolic Hypertension in the Elderly Program Cooperative Research Group (1993) Implications of the systolic hypertension in the elderly program. Hypertension 21:335-343

70. Dahlof B, Devereux R, de Faire U, Fyhrquist F, Hedner T, Ibsen H, Julius S, Kjeldsen S, Kristianson K, Lederballe-Pedersen O, Lindholm LH, Nieminen MS, Omvik P, Oparil S, Wedel H (1997) The Losartan Intervention for Endpoint reduction (LIFE) in hypertension study: rationale, design, and methods. Am $\mathbf{J}$ Hypertens 10:705-713
71. Okin PM, Devereux RB, Jern S, Kjeldsen SE, Julius S, Dahlof B (2000) Baseline characteristics in relation to electrocardiographic left ventricular hypertrophy in hypertensive patients: the Losartan intervention for endpoint reduction (LIFE) in hypertension study. Hypertension 36:766-773

72. Dahlof B, Devereux RB, Kjeldsen SE, Julius S, Beevers G, de Faire U, Fyhrquist F, Ibsen H, Kristiansson K, Lederballe-Pedersen O, Lindholm LH, Nieminen MS, Omvik P, Oparil S, Wedel H, LIFE Study Group (2002) Cardiovascular morbidity and mortality in the Losartan Intervention for Endpoint reduction in hypertension study (LIFE): a randomised trial against atenolol. Lancet 359:995-1003

73. Julius S, Alderman MH, Beevers G, Dahlof B, Devereux RB, Douglas JG, Edelman JM, Harris KE, Kjeldsen SE, Nesbitt S, Randall OS, Wright JT (2004) Cardiovascular risk reduction in hypertensive black patients with left ventricular hypertrophy: the LIFE study. J Am Coll Cardiol 43: $1047-1055$

74. Gassman JJ, Greene T, Wright JT Jr, Agodoa L, Bakris G, Beck GJ, Douglas J, Jamerson K, Lewis J, Kutner M, Randall OS, Wang SR (2003) Design and statistical aspects of the African American Study of Kidney Disease and Hypertension (AASK). J Am Soc Nephrol 14:S154-S165

75. Agodoa LY, Appel L, Bakris GL, Beck G, Bourgoignie J, Briggs JP, African American Study of Kidney Disease and Hypertension (AASK) Study Group (2001) Effect of ramipril vs amlodipine on renal outcomes in hypertensive nephrosclerosis: a randomized controlled trial. JAMA 285:2719-2728

76. Wright JT Jr, Bakris G, Greene T, Agodoa LY, Appel LJ, Charleston J, African American Study of Kidney Disease and Hypertension Study Group (2002) Effect of blood pressure lowering and antihypertensive drug class on progression of hypertensive kidney disease: results from the AASK trial. JAMA 288:2421-2431

77. Davis BR, Cutler JA, Gordon DJ, Furberg CD, Wright JT Jr, Cushman WC, Grimm RH, LaRosa J, Whelton PK, Perry HM, Alderman $\mathrm{MH}$, Ford CE, Oparil S, Francis C, Proschan M, Pressel S, Black HR, Hawkins CM (1996) Rationale and design for the Antihypertensive and Lipid Lowering Treatment to Prevent Heart Attack Trial (ALLHAT). Am J Hypertens 9:342-360

78. Grimm RH Jr, Margolis KL, Papademetriou VV, Cushman WC, Ford CE, Bettencourt J, Alderman MH, Basile JN, Black HR, DeQuattro VV, Eckfeldt J, Hawkins CM, Perry HM Jr, Proschan M (2001) Baseline characteristics of participants in the Antihypertensive and Lipid Lowering Treatment to Prevent Heart Attack Trial (ALLHAT). Hypertension 37:19-27

79. ALLHAT Collaborative Research Group (2000) Major cardiovascular events in hypertensive patients randomized to doxazosin vs chlorthalidone: the antihypertensive and lipid-lowering treatment to prevent heart attack trial (ALLHAT). JAMA 283:1967-1975

80. ALLHAT Officers and Coordinators for the ALLHAT Collaborative Research Group (2002) Major outcomes in high-risk hypertensive patients randomized to angiotensin-converting enzyme inhibitor or calcium channel blocker vs diuretic: the Antihypertensive and Lipid-Lowering Treatment to Prevent Heart Attack Trial (ALLHAT). JAMA 288:2981-2997

81. Norris K, Bourgoigne J, Gassman J, Hebert L, Middleton J, Phillips RA, Randall O, Rostand S, Sherer S, Toto RD, Wright JT Jr, Wang X, Greene T, Appel LJ, Lewis J, AASK Study Group (2006) Cardiovascular outcomes in the African American Study of Kidney Disease and Hypertension (AASK) Trial. Am J Kidney Dis 48:739-751

82. Zanchetti A, Julius S, Kjeldsen S, McInnes GT, Hua T, Weber M, Laragh JH, Plat F, Battegay E, Calvo-Vargas C, Cieśliński A, 
Degaute JP, Holwerda NJ, Kobalava J, Pedersen OL, Rudyatmoko FP, Siamopoulos KC, Störset O (2006) Outcomes in subgroups of hypertensive patients treated with regimens based on valsartan and amlodipine: an analysis of findings from the VALUE trial. J Hypertens 24:2163-2168

83. Jamerson K, Champion A, Zhou Q, Pepine C (2005) Verapamiland atenolol-based strategies are equally effective in black patients with hypertension and coronary artery disease: a subanalysis of the International Verapamil SR-Trandolapril Study (INVEST). Am J Hypertens 18(5 part 2):109A (abstract P286)

84. Weir MR, Bakris GL, Weber MA, Dahlof B, Devereux RB, Kjeldsen SE, Pitt B, Wright JT, Kelly RY, Hua TA, Hester RA, Velazquez E, Jamerson KA (2012) Renal outcomes in hypertensive Black patients at high cardiovascular risk. Kidney Int 81:568-576

85. Kizer JR, Dahlof B, Kjeldsen SE, Julius S, Beevers G, De Faire U, Fyhrquist F, Ibsen H, Kristianson K, Lederballe-Pedersen O, Lindholm LH, Nieminen MS, Omvik P, Oparil S, Wedel H, Wachtell K, Edelman JM, Snapinn SM, Harris KE, Devereux RB (2005) Stroke reduction in hypertensive adults with cardiac hypertrophy randomized to losartan versus atenolol: the Losartan Intervention for Endpoint reduction in hypertension study. Hypertension 45:46-52

86. Wright JT Jr, Dunn JK, Cutler JA, Davis BR, Cushman WC, Ford CE, Haywood LJ, Leenen FHH, Margolis KL, Papademetriou V, Probstfield JL, Whelton PK, Habib GB (2005) Outcomes in hypertensive black and nonblack patients treated with chlorthalidone, amlodipine, and lisinopril. JAMA 293: $1595-1608$

87. Okin PM, Kjeldsen SE, Julius S, Dahlöf B, Devereux RB (2012) Racial differences in sudden cardiac death among hypertensive patients during antihypertensive therapy: the LIFE study. Heart Rhythm 9:531-537

88. Yamal JM, Oparil S, Davis BR, Alderman MH, Calhoun DA, Cushman WC, Fendley HF, Franklin SS, Habib GB, Pressel SL, Probstfield JL, Sastrasinh S (2014) Stroke outcomes among participants randomized to chlorthalidone, amlodipine or lisinopril in ALLHAT. J Am Soc Hypertens 8:808-819

89. ALLHAT Officers and Coordinators for the ALLHAT Collaborative Research Group (2002) Major outcomes in moderately hypercholesterolemic, hypertensive patients randomized to pravastatin vs usual care: the Antihypertensive and LipidLowering Treatment to Prevent Heart Attack Trial (ALLHATLLT). JAMA 288(23):2998-3007

90. Akat PB, Bapat TR, Murthy MB, Karande VB, Burute SR (2010) Comparison of the efficacy and tolerability of telmisartan and enalapril in patients of mild to moderate essential hypertension. Indian J Pharmacol 42:153-156

91. Ali G, Kamili MMA, Kumar M, Rashid S, Dhar S, Pandita VR, Wadhwa MB (2001) Efficacy \& tolerability of losartan compared with amlodipine in the treatment of essential hypertension. JK Pract 8:140-142

92. Bhatia J, Mahajan P, Sikka M, Kalra OP (2001) Effect of various antihypertensive drugs on plasma fibrinogen levels in patients with essential hypertension. Indian J Med Sci 55:491

93. Devi P, Xavier D, Sigamani A, Pandey S, Thomas T, Murthy S, Sharma K, Bosco B, Mehta K, Joshi S, Gupta R, Singh G, Hiremath J, Ds C, Nambiar A, Pais P (2011) Effect of fixed dose combinations of metoprolol and amlodipine in essential hypertension: mARS-a randomized controlled trial. Blood Press Suppl 2:5-12

94. Goyal J, Khan ZY, Upadhyaya P, Goyal B, Jain S (2014) Comparative study of high dose mono-therapy of amlodipine or telmisartan, and their low dose combination in mild to moderate hypertension. J Clin Diagn Res 8:HC08-HC11

95. Jalal S, Sofi FA, Abass SM, Alai MS, Bhat MA, Rather HA, Lone NA, Siddiqi MA (2010) Effect of amlodipine and lisinopril on microalbuminuria in patients with essential hypertension: a prospective study. Indian J Nephrol 20:15-20

96. Jamali S, Mashori GR, Maher Z, Khan M (2008) Comparison of candesartan cilexetil and atenolol in essential hypertensive patients. Med Chan 14:28-31

97. Joglekar SJ, Jaguste V, Nanivadekar AS (1998) Prazosin GITS vs atenolol in patients with hypertension and normal lipid profile: a randomized, controlled multicenter study. Hyderabad Hypertension Study Group. J Assoc Physicians India Suppl $1: 41-51$

98. Misra KP, Joglekar SJ, Mukherjee S, Nanivadekar AS (1998) Prazosin GITS vs sustained release nifedipine in patients with hypertension and abnormal lipid profile: a randomized, controlled, multicenter study. Madras Hypertension Study Group. J Assoc Physicians India Suppl 1:30-40

99. Nandeesha H, Pavithran P, Madanmohan T (2009) Effect of antihypertensive therapy on serum lipids in newly diagnosed essential hypertensive men. Angiology 60:217-220

100. Pareek A, Karnik N, Salagre SB, Zawar SD, Joglekar VK, Chandurkar N, Naik GS (2008) Clinical effectiveness of lowdose chlorthalidone $(6.25 \mathrm{mg})+$ atenolol combination in stage I hypertensive patients: a multicenter, randomized, controlled study. Curr Med Res Opin 24:1771-1779

101. Satia MC, Shukla ML, Goyal RK (1995) Comparative effects of atenolol versus nifedipine on serum lipids and other biochemical parameters in diabetic and non-diabetic hypertensive subjects. Indian J Physiol Pharmacol 39:237-241

102. Shobha JC, Kumar TR, Raju BS, Kamath S, Rao M, Harwal, Babu A, Bhaduri J (2000) Evaluation of efficacy and safety of losartan potassium in the treatment of mild to moderate hypertension as compared to enalapril maleate. J Assoc Physicians India 48:497-500

103. Sumbria M, Negi PC, Sahai AK, Kaundal PK (2014) To compare the effect of telmisartan with metoprolol on arterial stiffness in hypertension: prospective randomized parallel group trial. Indian Heart J 66:415-421

104. Sundar S, Rajan AG, Somani PN, Kumar K (1991) The effects of antihypertensive agents on the quality of life in Indian hypertensives. Acta Cardiol 46:227-235

105. NCD Global Monitoring Framework (2015) http://www.who. int/nmh/global_monitoring_framework/en/. Accessed 30 Nov 2015

106. He FJ, MacGregor GA (2007) Blood pressure is the most important cause of death and disability in the world. Eur Heart J Suppl 9:B23-B28

107. Roth GA, Nguyen G, Forouzanfar MH, Mokdad AH, Naghavi M, Murray CJ (2015) Estimates of global and regional premature cardiovascular mortality in 2025. Circulation 132:1270-1282

108. Hippisley-Cox J, Coupland C, Robson J, Brindle P (2010) Derivation, validation, and evaluation of a new QRISK model to estimate lifetime risk of cardiovascular disease: cohort study using QResearch database. BMJ 341:c6624

109. Brindle P, May M, Gill P, Cappuccio F, D'Agostino R Sr, Fischbacher C, Ebrahim S (2006) Primary prevention of cardiovascular disease: a web-based risk score for seven British black and minority ethnic groups. Heart 92:1595-1602

110. Leenen FH, Dumais J, McInnis NH, Turton P, Stratychuk L, Nemeth K, Moy Lum-Kwong M, Fodor G (2008) Results of the Ontario survey on the prevalence and control of hypertension. CMAJ 178:1441-1449

111. SPRINT Research Group, Wright JT Jr, Williamson JD, Whelton PK, Snyder JK, Sink KM, Rocco MV, Reboussin DM, Rahman M, Oparil S, Lewis CE, Kimmel PL, Johnson KC, Goff DC Jr, Fine LJ, Cutler JA, Cushman WC, Cheung AK, Ambrosius WT (2015) A Randomized Trial of intensive versus standard blood-pressure control. N Engl J Med 373:2103-2116 
112. Flack JM, Sica DA, Bakris G, Brown AL, Ferdinand KC, Grimm RH Jr, Hall WD, Jones WE, Kountz DS, Lea JP, Nasser S, Nesbitt SD, Saunders E, Scisney-Matlock M, Jamerson KA (2010) Management of high blood pressure in Blacks: an update of the International Society on Hypertension in Blacks consensus statement. Hypertension 56:780-800

113. Eastwood SV, Tillin T, Chaturvedi N, Hughes AD (2015) Ethnic differences in associations between blood pressure and stroke in South Asian and European men. Hypertension 66:481-488

114. Flack JM, Bhatt DL, Kandzari DE, Brown D, Brar S, Choi JW, D’Agostino R, East C, Katzen BT, Lee L, Leon MB, Mauri L, O’Neill WW, Oparil S, Rocha-Singh K, Townsend RR, Bakris
G, SYMPLICITY HTN-3 Investigators (2015) An analysis of the blood pressure and safety outcomes to renal denervation in African Americans and Non-African Americans in the SYMPLICITY HTN-3 trial. J Am Soc Hypertens 9:769-779

115. Angell SY, De Cock KM, Frieden TR (2015) A public health approach to global management of hypertension. Lancet 385:825-827

116. Oparil S, Melino M, Lee J, Fernandez V, Heyrman R (2010) Triple therapy with olmesartan medoxomil, amlodipine besylate, and hydrochlorothiazide in adult patients with hypertension: the TRINITY multicenter, randomized, double-blind, 12-week, parallel-group study. Clin Ther 32:1252-1269 